(RESEARCH ARTICLE)

\title{
Peculiarities of cambial growth of some woody plants introduced in Kakheti region
}

\author{
Nadiradze Tamar* \\ Department of Natural Sciences, Doctor of Biological Sciences, Professor Iakob Gogebashvili Telavi State University, \\ Kartuli University str., Telavi 2200, Georgia.
}

Publication history: Received on 20 April 2020; revised on 29 April 2020; accepted on 30 April 2020

Article DOI: https://doi.org/10.30574/wjarr.2020.6.2.0112

\begin{abstract}
The paper deals with the study of cambial growth of 32 species of woody plants, carried out in Kakheti region during six years. We have studied several plants and found out that they begin their cambial growth (with the exception of some oak species) after bud opening. According to calendar time, two groups of plants were distinguished: the first group of the plants began cambial growth in late March and at the beginning of April. These plants are as follows: Larix decidua Mill and Larix leptolepis Gord., Acer negundo L., Aesculus carnea Haine., Aesculus hippocastanum L. and 20 other species. The second group of the plants began cambium activity in May. These are plant species like Picea orientalis (L.) Link., Pinus griffithii Mc Cleland, Quercus occidentalis J. Gay., Magnolia grandiflora L. and others. The earliest completion of cambial growth was observed in the lateral branches of spruce, fir and other trees. The latest accomplishment (the first half of October) of cambial growth occurred in case of Cedrus atlantica Mannetti. and Cedrus deodara Loud., Pinus griffithii Mc Clel., Magnolia grandiflora L., Firmiana platanifolia Schott., etc. The endogenous rhythm of the investigated plants (with few exceptions) is in synchronous connection with the climate of Kakheti region, so we consider these plants to be interesting species for the decorative gardening and forestry of Telavi district, and deserve widespread distribution.
\end{abstract}

Keywords: Bud opening; Duration of vegetation; Secondary meristem; Cambial growth

\section{Introduction}

Kakheti is the region in Eastern part of Georgia (the country) on $41^{\circ} 43^{\prime} N, 44^{\circ} 50^{\prime} E$. The region is well known by diversity of the natural conditions. It is quite well protected from strong winds, relatively open from the southeast, especially in autumn and winter. The humid air and precipitation often flow from the Caspian Sea. There are more than 200 species of introduced plants living in the area.

While evaluating acclimatization and adaptation peculiarities of the introduced plants, their growth and development characteristics in the new environment are considered to be an important factor. It is essential to explore the duration of plant vegetation in the new environment, the length of cambial growth or the division of secondary meristem cells in order to assess the vegetative development and preparation for overwintering.

Gulisashvili [1], Gvianidze [2], Germenyak [3] Lobzhanidze [4], Tsitsvidze [5, 6] conducted the most significant research on cambial growth in Georgia.

Despite the richness of existed works, cambial growth has not been thoroughly investigated. Many ornamental and interesting species in forest farming have not been studied. The impact of environmental factors on duration of cambial growth, early and late timber production has not been estimated either. Elaboration of the above mentioned issues have both, theoretical and practical importance, e.g. irrigation, soil fertilization, transplantation, propagation and other agrotechnical activities should be related to the biochemical and physiological processes. The research aims at the study the peculiarities of cambial growth of some introduced woody plants in Kakheti region.

\footnotetext{
* Corresponding author: Nadiradze Tamar
}

Copyright (C) 2020 Author(s) retain the copyright of this article. This article is published under the terms of the Creative Commons Attribution Liscense 4.0. 


\section{Sources and methods}

Presented exploration is the first study of cambial growth in Kakheti region [7].

In 2012-2018 we studied the regularity of cambium action in 1-3 year old branches of 32 woody plant species introduced in the region of Kakheti. Several individuals that grow in the same environmental conditions and have the same rhythm of biological development were selected.

When taking the samples for analysis, the age of the plant, lighting, crown exposure and vegetative state were taken into account. The samples for analysis (3-35 cm long 1-3-year-old twigs) were taken once every 5 days during bud opening and apical growth completion, and once every 10 days during the vegetation period. The investigation was conducted in accordance to the methodical instructions by Lobzhanidze [4], Tsitsvidze [5] and Elagin [8]. Perennial data were processed by using the method of variation statistics.

The obtained results are presented in Table 1.

\section{Results and discussion}

The research results made it possible to estimate that bud opening in the branches of the investigated plants precedes the activation of cambium. However, some species are the exception. For example, Quercus iberica Stev. began division of the secondary meristem cells in the lateral branches 2-3 days earlier than bud opening. However, some trees were observed to have several swollen and 1-2 opened buds in the tree crowns. This feature was revealed by Quercus rubra L. and Quercus alba L. Cambial growth was also observed in Magnolia grandiflora L. and Gymnokladus dioicus (L.) C.Koch. before bud opening (average data).

The radial growth of woody plants is stimulated by the division of primary meristem cells that often occurs in swollen buds and usually precedes the activation of the cambium. The observations have shown that in winter, defolation and folation are followed by the renewal of cambium activity.

During the reserch work the earliest (the end of March) bud opening and consequently, the activation of cambium was obsereved in Larix decidua Mill. and Larix leptolepis Gord., Acer negundo L., Aesculus carnea Haine. and Aesculus hippocastanum L.

From 2012 to 2018, the earliest activation of cambium in the branches of Cedrus atlantica Mannetti.was observed in 2014 (April 10) and the latest in 2017 (April 28), when the minimum air temperature was 5.2-8.6 degrees.

Most of the investigated plants began activation of their cambium in April. Among the plants, the renewal of cambial growth was observed in 18 species of plants in the first half of April and it was the second half of April in case of 12 species. Relatively late in May, the division of the secondary meristem cells began in the branches of Cedrus atlantica Mannetti., Picea orientalis (L.) Link., Pinus griffithii Mc Cleland, Quercus occidentalis J. Gay., Magnolia grandiflora L., and Firmiana platanifolia Schott. For example, Firmiana platanifolia Schott. begins the activation of cambium in the first decade of May. The expected deviation in both directions is observed within 4 days. During the research period Firmiana platanifolia Schott. began vegetation when the minimum air temperature was $5^{\circ}-13^{\circ} \mathrm{C}$.

Late activation of cambium is characteristic of Albizia julibrissin Durazz. During the research period, May 6 is considered to be the approximate date of its cambial growth. Due to the fact that Albizia julibrissin Durazz., begins its vegetation late and the thermal regime is relatively stable at the end of the spring, the arithmetic mean of the expected deviation is insignificant and the variation coefficient is relatively low. The expected deviation can be 4 days and the variation ratio is $10.4 \%$.

Thus, in the branches of the investigated plants, bud opening and cambium action begins when the minimum daily air temperature exceeds $5-10^{\circ} \mathrm{C}$ and the plant is ready to start the process of vegetation. The investigated plants begin the action of cambium when the damage from late frosts is not expected.

The completion of the cambium action and its duration is quite an interesting process. The selected plants complete the cambium action in August-September, rarely in October, even more rarely in November. i.e. cambial growth ends earlier than the vegetation period. For instance, in Tsinandali Park [7], Abies cephalonica Loud., Picea orientalis (L.) Link, and Picea pungens Engelm., complete the cambial growth about 3 months earlier and Larix decidua Mill., and Larix leptolepis 
Gord. end This process 2-2.5 months earlier. In case of Ginkgo biloba L., Pinus pallasiana Lamb., Pinus strobus L., and Cryptomeria japonica D. Don., it occurs two months earlier, and Cedrus atlantica Mannetti. and Cedrus deodara Loud., Maclura pomifera (Raf.) Schneid., Magnolia grandiflora L., Cercis siliquastrum L., Gymnokladus dioicus (L.) C.Koch, continue their cambium action still in the first half of October i.e. their radial growth is 1.5-2 months shorter compared with the vegetation period of the plants in the region where the research was carried out.

Juglans regia L. and Juglans nigra L. complete their cambial growth almost simultaneously, however longer-growing is characteristic of Juglans regia L. Among the oak trees, Quercus occidentalis J. Gay. has a shorter growing period. This might be explained by the fact that it starts to grow late and stops it in the autumn (the end of September), at a minimum temperature of $10^{\circ} \mathrm{C}$.

Table 1 Cambium action in 1-3 year old sprouts

\begin{tabular}{|c|c|c|c|c|c|c|c|}
\hline \multirow[b]{2}{*}{ \# } & \multirow[b]{2}{*}{ Species } & \multirow{2}{*}{$\begin{array}{l}\text { Bud opening } \\
\text { (Day/Month) }\end{array}$} & \multicolumn{2}{|l|}{ Beginning } & \multicolumn{2}{|l|}{ End } & \multirow{2}{*}{$\begin{array}{l}\text { Duration } \\
\text { (Days) }\end{array}$} \\
\hline & & & $\begin{array}{l}\text { M } \\
\text { (medium) }\end{array}$ & $\pm 2 \mathrm{~m}$ & $\begin{array}{l}\text { M } \\
\text { (medium) }\end{array}$ & $\pm 2 \mathrm{~m}$ & \\
\hline 1 & Cedrus atlantica Manetti & $12 / 04$ & 19.05 & 12.0 & 18.10 & 8.4 & 152 \\
\hline 2 & Larix decidua Mill. & $23 / 03$ & 10.04 & 8.2 & 4.09 & 6.4 & 147 \\
\hline 3 & Larix leptolepis Gord. & $28 / 03$ & 4.04 & 4.8 & 9.09 & 10.4 & 157 \\
\hline 4 & Picea orientalis(L.) Link. & $1 / 05$ & 2.05 & 8.0 & 19.08 & 12.0 & 109 \\
\hline 5 & Pinus griffithii Mc. Cleland. & $30 / 04$ & 19.05 & 6.6 & 10.10 & 10.0 & 142 \\
\hline 6 & Quercus alba L. & $18 / 04$ & 15.04 & 6.0 & 21.09 & 6.4 & 160 \\
\hline 7 & Quercus iberica Stev. & $18 / 04$ & 16.04 & 6.0 & 26.09 & 10.4 & 164 \\
\hline 8 & Quercus rubra L. & $14 / 04$ & 12.04 & 5.4 & 11.09 & 14.0 & 153 \\
\hline 9 & Magnolia grandiflora L. & $15 / 05$ & 9.05 & 12.4 & 4.10 & 10.0 & 147 \\
\hline 10 & Acer negundo L. & $19 / 03$ & 8.04 & 6.0 & 22.09 & 11.0 & 167 \\
\hline 11 & Gimnocladus dioicus L. & $20 / 04$ & 13.04 & 7.0 & 3.10 & 3.6 & 163 \\
\hline 12 & Aesculus carnea Haine & $20 / 03$ & 4.04 & 4.6 & 23.09 & 12.6 & 172 \\
\hline 13 & Aesculus hippocastanum L. & $30 / 03$ & 7.04 & 2.3 & 27.09 & 16.2 & 173 \\
\hline
\end{tabular}

$$
\begin{aligned}
& \text { Legend: } \mathrm{M} \text { - arithmetic mean of the beginning and ending. } \\
& \pm 2 \mathrm{~m} \text { - deviation from the simple average in both directions (in days). }
\end{aligned}
$$

It is interesting how the radial growth of Sophora japonica L. passes. The interest was aroused because the plant blooms (only a few flowers) in the summer and sometimes it continues growing until the end of September. It starts vegetation in the first half of April, and in 2012-2016, the activation of cambium in 1-3-year-old shoots began around April 9, 2-16 days after bud opening, and ended in September-October. The average duration of the active cambium was 164 days.

The completion of cambial growth of Liriodendron tulipifera L., turned out to be quite variable. The average date is October 4, with an expected deviation of 12 days from the average date. In 2007, the plant completed its cambial growth on October 3 , when the minimum air temperature was $10.2{ }^{\circ} \mathrm{C}$ and the maximum $-22.2{ }^{\circ} \mathrm{C}$. In 2009 , the growth was completed on September 15. The latest growth (October 20), within the research period was observed to take place in 2015.

Lagerstroemia indica L. blossoms almost the whole summer, along with Sophora japonica L. and Albizia julibrissin Durazz. It completes its cambial growth in October.

Short-term growth is characteristic of cold latitudes and high mountains, while prolonged growing process is typical for subtropical and moderately warm latitudes. Under the conditions of the cold climate, a large group of plants changed the continuous action of cambium into seasonal action. [7] 


\section{Conclusion}

Thus, the investigated plants, with few exceptions, begin their cambial growth after bud opening i.e. cambial growth is preceded by the division of primary meristem cells. The action of cambium in the branches of Larix decidua Mill and Larix leptolepis Gord., Acer negundo L., Aesculus carnea Haine., Aesculus hippocastanum L. and 20 other plant species were observed in late March and at the beginning of April. Cambial growth in the branches of Picea orientalis (L.) Link., Pinus griffithii Mc Cleland, Quercus occidentalis J. Gay, Magnolia grandiflora L. and other plant species began in May. Spruce, fir, and some other plants have the earliest completion of the cambial growth; The latest completion of cambial growth (the first half of October) is observed in case of Cedrus atlantica Mannetti. and Cedrus deodara Loud., Pinus griffithii Mc Cleland, Magnolia grandiflora L., Firmiana platanifolia Schott. and others. The duration of their growth correlated with frost resistance. However, with some exceptions, the endogenous rhythm of the investigated plants is synchronous with the climate of Kakheti region, so we reckon that all these species are interesting and deserve to be widespread in landscape gardening of Kakheti region.

\section{Compliance with ethical standards}

\section{Disclosure of conflict of interest}

The author declares no conflicts of interest.

\section{References}

[1] Gulisashvili V. (1967). The origin of the woody vegetation of the subtropical climate and the development of its hereditary features. Metsniereba, Tbilisi, GE.

[2] Gvianidze D. (1981). Patterns of radial growth of oak wood. Biology, ecology and systematics of the introduced and local flora of Adjara, 12(8).

[3] Germenyak V. (1982). The activity of cambium in 2-3-year-old shoots of some Caucasian oaks in the Tbilisi Botanical Garden. Plant introduction and green development, 14 (83).

[4] Lobzhanidze E. (1961). Cambium and formation of annual wood ring. Metsniereba, Tbilisi, GE.

[5] Tsitsvidze A. (1981). Patterns of cambium activity and structure of woody coniferous exotics. Biology, ecology and systematics of introduced and local flora of Adjara, 25.

[6] Tsitsvidze A. (1973). The peculiarities of growth and development of coniferous plants in Adjara. Metsniereba, Tbilisi, GE.

[7] Nadiradze T. (2011). Adaptation results of introduced woody plants in Tsinandali arboretum. Biodiversity of Georgia, Tbilisi. GE.

[8] Elagin I. (1962). A technique for studying the processes of formation of an annual ring in oak. In: Phenology of woody plants. Metsniereba, Tbilisi, GE.

\section{How to cite this article}

Nadiradze T. (2020). Peculiarities of cambial growth of some woody plants introduced in Kakheti region. World Journal of Advanced Research and Reviews, 6(2), 01-04. 